\title{
ADDITIONAL INFORMATION ON GREAT BLUE HERON COLONIES IN MANITOBA
}

\author{
by Kees Vermeer, Canadian Wildlife Service, Edmonton, Alberta \\ and David R. M. Hatch, Oak Lake, Manitoba
}

Island colonies of Great Blue Herons (Ardea herodias) on large lakes in Manitoba were surveyed in 1969 (Vermeer, K., Blue Jay, 28:84-86, 1970). In 1971 , a survey was made of Great Blue Heron colonies in other parts of Manitoba by plane, boat and automobile. (Inasmuch as the survey was not exhaustive and colonies may therefore have been missed, further information on heronries will be much appreciated by the writers.)

The numbered colonies in Fig. 1 are identified in Table 1. Ten colonies with 258 active nests were found in Duck Mountain Forest Reserve, which includes Duck Mountain Provincial Park, and five colonies with 197 active nests were found in Riding Mountain $\mathrm{Na}$ tional Park (Fig. 1). One colony (no. 22) with 44 active nests was in Turtle Mountain Provincial Park and two (no.'s 34 and 35) with 52 active nests were in Whiteshell Provincial Park. These 18 colonies with 551 nests are protected by park or reserve boundaries in Manitoba, compared with one colony of nine nests in Elk Island National Park, Alberta and four colonies with a total of 114 nests in Backes Island Wildlife Refuge, Horseshoe Lake Wildlife Refuge, Meadow Lake Provincial Park and Duck Mountain Provincial Park in Saskatchewan.

Our survey of heronries in the Duck Mountain area has resulted in better protection for heronries there. D. R. Witty, park planner, wrote that the information provided on heronries was: "of invaluable assistance to us in our zoning of Duck Mountain Provincial Park. For instance in recognition of colonies 4 and 5, Elk and Beautiful Lakes have been zoned as non-power boating water bodies to protect these major nesting sites from excessive human disturbances." Unfortunately, all colonies in Manitoba are not so safe from man-caused habitat changes. For instance, the large colony (no. 21) near
Table 1. Location and size of active Great Blue Heron colonies observed in Manitoba in 1971.

\begin{tabular}{|c|c|c|c|c|}
\hline $\begin{array}{c}\text { Map } \\
\text { No. } \\
\text { (Fig } \\
\text { 1) } \\
\end{array}$ & $\begin{array}{c}\text { No. } \\
\text { active } \\
\text { nests }\end{array}$ & Section & Township & Range \\
\hline 1 & 8 & 14 & 33 & $25 \mathrm{~W} 1$ \\
\hline 2 & 55 & 13 & 32 & $25 \mathrm{~W} 1$ \\
\hline 3 & 11 & 31 & 31 & $25 \mathrm{~W} 1$ \\
\hline 4 & 20 & 14 & 30 & $26 \mathrm{~W} 1$ \\
\hline 5 & 41 & 6 & 30 & $24 \mathrm{~W} 1$ \\
\hline 6 & 22 & 17 & 29 & $26 \mathrm{~W} 1$ \\
\hline 7 & 6 & 27 & 28 & $26 \mathrm{~W} 1$ \\
\hline 8 & 68 & 24 & 28 & $35 \mathrm{~W} 1$ \\
\hline 9 & 22 & 15 & 27 & $26 \mathrm{~W} 1$ \\
\hline 10 & 5 & 28 & 26 & $25 \mathrm{~W} 1$ \\
\hline 11 & 31 & 18 & 26 & $29 \mathrm{~W} 1$ \\
\hline 12 & 42 & 16 & 23 & $25 \mathrm{~W} 1$ \\
\hline 13 & 55 & & 22 & $20 \mathrm{~W} 1$ \\
\hline 14 & 50 & 16 & 21 & $23 \mathrm{~W} 1$ \\
\hline 15 & 33 & & 21 & $19 \mathrm{~W} 1$ \\
\hline 16 & 17 & 30 & 20 & $22 \mathrm{~W} 1$ \\
\hline 17 & 34 & 13 & 19 & $21 \mathrm{~W} 1$ \\
\hline 18 & 34 & 16 & 10 & $14 \mathrm{~W} 1$ \\
\hline 19 & 21 & 21 & 9 & $17 \mathrm{~W} 1$ \\
\hline 20 & 19 & 16 & 9 & $10 \mathrm{~W} 1$ \\
\hline 21 & 89 & 36 & 3 & $13 \mathrm{~W} 1$ \\
\hline 22 & 44 & 17 & 1 & $21 \mathrm{~W} 1$ \\
\hline 23 & 12 & 9 & 1 & $22 \mathrm{~W} 1$ \\
\hline 24 & 9 & 2 & 1 & $20 \mathrm{~W} 1$ \\
\hline 25 & 127 & 12 & 25 & $10 \mathrm{~W} 1$ \\
\hline 26 & ca. $50 *$ & 6 & 23 & $10 \mathrm{~W} 1$ \\
\hline 27 & ca. 20 & & 44 & 4 E1 \\
\hline 28 & ca. 12 & ... & 39 & 7 \$1 \\
\hline 29 & ca. 12 & & 34 & $16 \mathrm{E} 1$ \\
\hline 30 & 26 & 1 & 32 & 4 E1 \\
\hline 31 & 23 & 11 & 18 & $15 \mathrm{E} 1$ \\
\hline 32 & 16 & 8 & 17 & 7 E1 \\
\hline 33 & 28 & 8 & 16 & $15 \mathrm{E} 1$ \\
\hline 34 & 7 & 36 & 11 & $14 \mathrm{E} 1$ \\
\hline 35 & 45 & 33 & 8 & $17 \mathrm{E} 1$ \\
\hline
\end{tabular}

Pickerel Lake**

\begin{tabular}{cccc}
10 & 35 & 41 & $15 \mathrm{~W} 1$ \\
$\begin{array}{c}\text { Head River*** } \\
\text { ca. 50* }\end{array}$ & 18 & 52 & $20 \mathrm{~W} 1$ \\
\hline
\end{tabular}

*includes active and inactive nests

*** Discovered in 1970, but information received after map had been drawn. 
Glenora is in danger of being destroyed because the lessee of the land on which the heronry is located intends to clear the nesting trees for cultivation purposes. One colony (no. 31) has been saved from timber salvage through intervention of three conservationists, R. W. Nero, L. Bidlake and L. G. Yarn after the Abitibi Pulp and Paper Company agreed to leave the trees surrounding that colony.

The tree and aquatic habitats of active heronries are shown in Tables 2 and 3 respectively. Twenty-four of the 30 colonies shown in Table 2 were situated in one tree species. Besides the trees indicated in Table 2, herons also nested in birch (Betula occidenta- lis), ash (Fraxinus campestris) and elm (Ulmus americanus). Some colonies were entirely in dead trees (no. 5,22 and 25) while others were entirely in living trees (no. 8). One-third of the 34 colonies shown in Table 3 were located in water. The 10 heronries situated in dead trees (Table 2) were found in such flooded terrain. Trees will die when inundated for a lengthy period and colony sites may disappear because the dead trees eventually blow down.

Although fire may be a possible hazard to nesting colonies, two heronries in which there had been fires showed surprisingly little damage. The bush surrounding the large heronry at

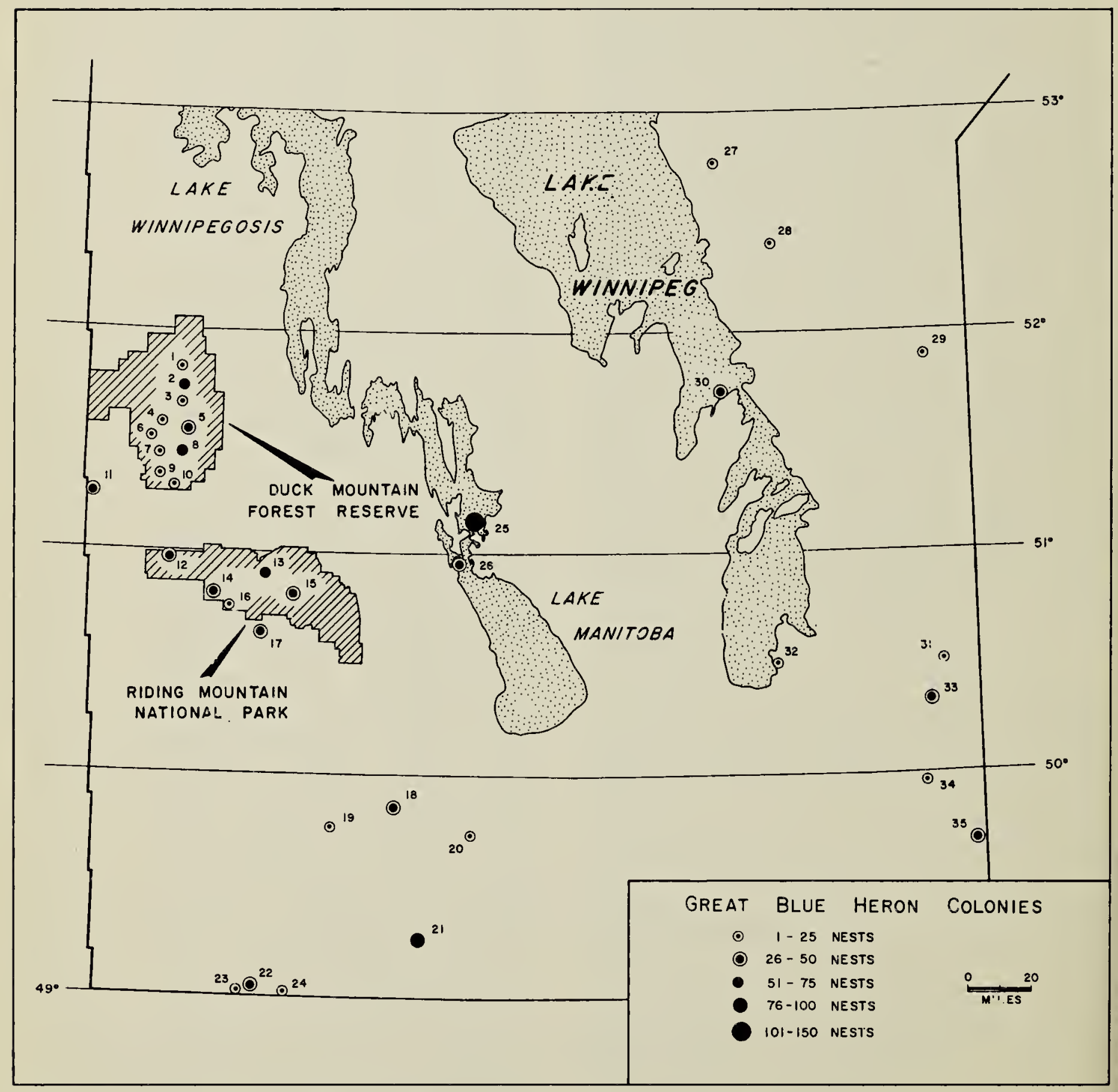

Fig. 1 Location and approximate size of Great Blue Heron colonies in Manitoba, 1971. 
Richard Point (no. 25) was struck by lightning the day before the junior writer visited the colony. The resulting fire burned one-third of the undergrowth beneath the colony but only four nesting trees were destroyed. Young herons in nesting trees still standing appeared to be alive and well. A ground fire which swept through another heronry (no. 31) in June 1971 caused little damage to the nesting trees and no young herons appeared to have died because of smoke inhalation.

Some heronries (no. 18, 19, 20 and 21) may have suffered raccoon (Procyon lotor) predation. The ground around the nesting trees was covered with raccoon tracks and many nests which had fallen to the ground showed raccoon hair on their edges. Two nests with eggs, of which the contents had been eaten, showed signs of raccoon predation.

Table 4 shows 11 colonies which are known to have disappeared, mostly during the last decade. Local residents blamed raccoons for destruction of the colonies at Hilton, Oak Lake, Virden and Pipestone, human disturbance for the disappearance of those at Singush and Whitemud lakes, and a storm for the destruction of another colony (1327-25 W1) in the Duck Mountains. The colony at Basswood disappeared because the nesting site was cleared for cultivation.

A mixed colony of Double-crested Cormorants (Phalacrocorax auritus)

Table 2. Tree habitat of 30 active Great Blue Heron colonies.

\begin{tabular}{lccc}
\hline $\begin{array}{l}\text { Dominant } \\
\text { tree species } \\
\text { in colony }\end{array}$ & $\begin{array}{c}\text { No. } \\
\text { colonies }\end{array}$ & \multicolumn{2}{c}{$\begin{array}{c}\text { Prevalent condition of } \\
\text { nesting trees }\end{array}$} \\
\cline { 2 - 4 } & Alive & Dead \\
\hline $\begin{array}{l}\text { Populus } \\
\text { tremuloides }\end{array}$ & 16 & 9 & 7 \\
$\begin{array}{l}\text { Populus } \\
\text { balsamifera }\end{array}$ & 3 & 1 & 2 \\
$\begin{array}{l}\text { Salix } \\
\text { amygdaloides }\end{array}$ & 1 & 1 &.. \\
$\begin{array}{l}\text { Picea mariana } \\
\text { Pinus }\end{array}$ & 9 & 8 & 1 \\
banksiana & 1 & 1 &.. \\
\hline Total & 30 & 20 & 10 \\
\hline
\end{tabular}

and Great Blue Herons was found on an island in Stewart Lake (no. 17). There were 20 heron nests in live and 13 in dead balsam poplar trees (Populus balsamifera) with one nest in live white birch (Betula papyrifera). There were 14 active nests of Double-crested Cormorants which were generally situated on lower branches than those of

Table 3. Aquatic habitat of 34 active Great Blue Heron colonies.

\begin{tabular}{|c|c|c|c|}
\hline \multirow{2}{*}{$\begin{array}{l}\text { Nesting } \\
\text { location }\end{array}$} & \multirow{2}{*}{$\begin{array}{l}\text { No. } \\
\text { colonies }\end{array}$} & \multicolumn{2}{|c|}{$\begin{array}{l}\text { Prevalent location of } \\
\text { nesting trees }\end{array}$} \\
\hline & & on land & In water \\
\hline Lake island & 9 & 8 & 1 \\
\hline Lake edge & 6 & 6 & \\
\hline River bank & 4 & 2 & 2 \\
\hline River island & 1 & 1 & .. \\
\hline Pond & 5 & 1 & 4 \\
\hline Beaverpond & 3 & 1 & 2 \\
\hline Small swamp & p 4 & 3 & 1 \\
\hline \multicolumn{4}{|c|}{ Junction of lake } \\
\hline and creek & 2 & & 2 \\
\hline Total & 34 & 22 & 12 \\
\hline
\end{tabular}

Table 4. Great Blue Heron coolnies no longer active in Manitoba.

\begin{tabular}{lrc}
\hline Locality & $\begin{array}{c}\text { Section } \\
\text { Township } \\
\text { and Range }\end{array}$ & $\begin{array}{c}\text { Last } \\
\text { year known } \\
\text { in use }\end{array}$ \\
\hline Hilton & $9-6-16$ W1 & 1966 \\
Oak Lake & $16-8-24$ W1 & 1957 \\
Virden & $4-11-25$ W1 & 1965
\end{tabular}

Maple Leaf,

Pipestone 30-6-25 W1

1960

Basswood 19-15-19 W1

1962

or 1963

Hooper Lake ?-15-27 W1

Whiteshell

Prov. Park 5-11-14 E1

1965

Whiteshall

Prov. Park 28-13-16 E1

1965

Duck Moun-

tains 13-27-25 W1

1967

Duck Mts.,

Island in Singush

Lake 30-30-24 W1

1964

Duck Mts.,

Island in Whitemud

Lake 14-30-25 W1

1964

Turtle Mountain

Prov. Park 12-1-21 W1

1969 
herons. Eleven of the cormorant nests were in live and three were in dead balsam poplars. Another mixed colony of Double-crested Cormorants and Great Blue Herons in the Turtle Mountain area (no. 24), was in a flooded stand of dead aspen poplar. Both heron and cormorant nests varied greatly in height above the ground. Of the 20 active nests present, 11 were used by the cormorants and nine by the herons. A young Great Horned Owl (Bubo virginianus) was found in a former Great Blue Heron nest in the large heronry on Richard Point (no.
25). The tree in which the young owl was found contained two other nests with young herons. Common Grackles (Quiscalus quiscula) had built nests in the bottom of 12 heron nests in the same colony. Common Grackles were also observed nesting in the bottom of six Great Blue Heron nests in the heron colony at Kawinaw Lake in 1971.

\section{Acknowledgments}

The authors appreciate the help of at least 18 persons who provided information or asisisted with locating heronries.

\section{TRAILL'S FLYCATCHER NESTING AT SASKATOON}

\section{by Wayne C. Harris, Raymore}

At approximately 9:00 a.m. on July 23, 1971 a bird tentatively identified as a Traill's Flycatcher (Empidonax traillii) was observed by J. A. Wedgwood, S. J. Shaddick and myself four miles north and four miles west of Ardath (within the Saskatoon study area). The bird was giving alarm notes and seemed unwilling to leave the area. Though these actions led us to believe that there was a nest, a search of the area revealed nothing.

Another visit was made at 8:30 p.m. on the same day in an attempt to locate a nest. Following a thorough search, we flushed a small flycatcher from a small patch of rose bushes, and a nest containing four eggs was found $2 \frac{1}{2}$ feet high in the crotch of a rose bush. The habitat was shrubbery (rose, willow, red-osier dogwood, and snowberry) near the bank of a permanent creek. We left the area with the identification of the bird still in doubt as no singing male was heard in the vicinity of the nest.

On July 31, J. B. Gollop, J. A. Wedgwood and the writer revisited the nest in order to verify the identification of the bird. We found the female still on the nest and she was not flushed. Shortly, a male Traill's Flycatcher began singing from the top of a tree. A survey of the area revealed five Traill's Flycatcher in the vicinity (including the incubating female).
Another nest of the same construction as the first was found and, although the young had already fledged, it appeared that this nest was also that of a Traill's Flycatcher, something which could account for the number of birds of this species in the area.

When the female was finally flushed from the active nest, it was found to contain two eggs and two young. This was the last time the nest was visited; hence the outcome is not known.

Traill's Flycatcher was regarded as an uncommon migrant in the Saskatoon area and until this year there were no records between June 13 and August 19 (records from the "Saskatoon Bird Review"). This year there were several records between these dates. C. S. Houston observed one eight miles south of Saskatoon on June 19, and apparently the same individual was observed by the author in the same locality on June 22, 26, and July 5. A nest could not be located in this area although the bird was singing on three of the four sightings.

The above records not only constitute the first summer records but also include the only known breeding record for this area. This, however, is not the first breeding record for southern Saskatchewan; W. Earl Godfrey (The birds of Canada, Natl. Mus. Can. Bull. 203. 1966) states that Traill's Flycatcher breeds locally in the southern part of the province. 